UDK 528.283

\title{
ASTRONOMINIO DIENOVIDINIO NUSTATYMO PAGAL SAULĖS VALANDINI KAMPĄ GALIMYBIŲ TYRIMAS
}

\author{
Petras Petroškevičius, Romuald Obuchovski \\ Geodezijos ir kadastro katedra, Vilniaus Gedimino technikos universitetas, Geodezijos institutas, \\ Saulètekio al. 11, LT-10223 Vilnius-40, Lietuva, el.paštas: gi@ap.vtu.lt
}

Iteikta 200512 05, priimta 20051214

\begin{abstract}
Santrauka. Pateikiami astronominio dienovidinio nustatymo galimybių tyrimo rezultatai. Dienovidinio krypčiai gauti nagrinejjamas astronominio azimuto nustatymo pagal Saulès valandini kampą metodas. Ištirtos geriausios Saulès azimuto nustatymo sąlygos. Išnagrinèta punkto ir Saulès koordinačių paklaidų itaka. Nustatyta Saulès valandinio kampo paklaidos itakos priklausomybé nuo Saulès deklinacijos ir platumos. Nurodytos platumos ir deklinacijos paklaidų įtakos mažinimo galimybès. Išnagrinèti horizontaliojo kampo tarp pasirinktos krypties ir Saulès matavimo ypatumai. Išanalizuota Saulès regimojo spindulio ir azimuto kitimo pagreičio pokyčių ịtaka. Remiantis gautais tyrimų rezultatais galima pasirinkti tinkamiausia laika krypties astronominiam azimutui, o kartu ir astronominio dienovidinio krypčiai nustatyti, atsižvelgiant i žinomas parametrų paklaidas, punkto platumą ir metų laiką.
\end{abstract}

Prasminiai žodžiai: astronominis dienovidinis, astronominis azimutas, geriausios sąlygos Saulès azimutui nustatyti, astronominio azimuto nustatymas pagal Saulès valandini kampa.

\section{Ivadas}

Astronominio dienovidinio krypti galima nustatyti astronominiais metodais: pagal išmatuotus Saulès zenitinius nuotolius, Šiaurinès valandini kampa [1] ir kt. [2]. Patogu astronominio dienovidinio krypti rasti pagal Saulès valandini kampa nustatant tam tikros krypties astronomini azimutą [1]. Todèl svarbu ištirti šio metodo galimybes, kai krypties astronomini azimutą siekiama nustatyti $10^{\prime \prime}$ ar didesniu tikslumu. Straipsnyje pateikiami atliktų tyrimų rezultatai.

\section{Azimuto nustatymas pagal Saulès valandinị kampą}

Krypties astronominiam azimutui $a$ nustatyti teodolitu matuojamas horizontalusis kampas $Q$ tarp pasirinktos krypties ir Saulès. Matavimų momentu Saulès azimutas $A_{N}$ atskaičiuojamas nuo krypties i šiaurę, randamas pagal jos pusiaujines ir punkto astronomines koordinates sprendžiant pagal paralaksini trikampi (1 pav.)

$$
\tan A_{N}=\frac{\sin t}{\sin \varphi \cos t-\cos \varphi \tan \delta}
$$

čia $\varphi-$ punkto, kuriame nustatomas azimutas, astronomine platuma; $t=s-\alpha$ - Saulès valandinis kampas; $\delta$ ir $\alpha$ - Saulès regimosios pusiaujinès koordinates deklinacija ir rektascensija; $s=T+u-$ vietinis žvaigždžių laikas; $T$ - chronometro rodmuo ir $u$ - chronometro pataisa Saulès stebèjimo momentu.

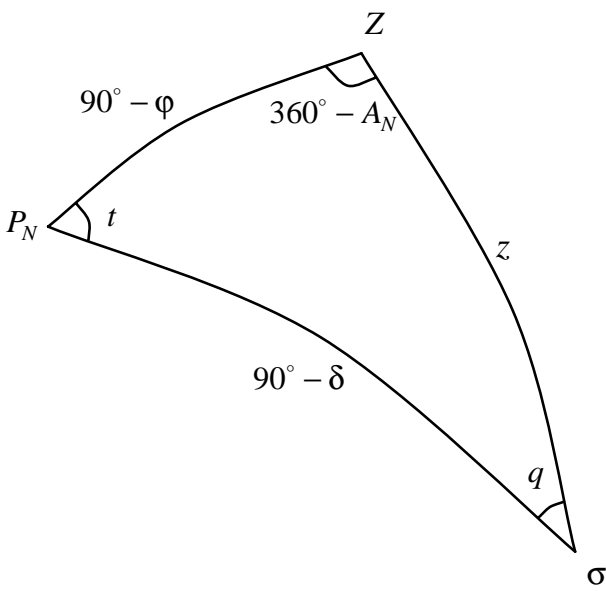

1 pav. Paralaksinis trikampis

Fig 1. Parallax triangle

Chronometro pataisa gaunama naudojantis laiko signalų prièmimo rezultatais. Signalai priimami prieš ir po matavimų. Pirmiausia ir skaičiuojamos tų momentu chronometro pataisų vietinio žvaigždžiu laiko atžvilgiu reikšmès $u_{1}$ ir $u_{2}$. Taikomos formulès:

$$
\begin{aligned}
& u=s-T, \\
& s=S_{0}+U T 1+U T 1 \mu+\lambda,
\end{aligned}
$$

čia $S_{0}$ - žvaigždžių laikas Grinvičo vidutini vidurnaktị; $U T 1$ - pasaulinis laikas signalo perdavimo momentu; $U T 1 \mu$ - vidutinio laiko vienetu pavertimo ì žvaigždžių 
vienetus pataisa; $\mu=1 / 365,24219879 ; \quad \lambda-$ punkto astronominè ilguma. Chronometro pataisa Saulès stebejjimo momentu skaičiuojama pagal formulę

$$
u=u_{1}+\omega\left(T-T_{1}\right)^{h}
$$

čia $\omega$ - valandinè chronometro eiga -

$$
\omega=\frac{u_{2}-u_{1}}{\left(T_{2}-T_{1}\right)^{h}} .
$$

Krypties astronominis azimutas skaičiuojamas pagal formulę

$$
a=A_{N}+Q
$$

Nustatytu pasirinktos krypties astronominiu azimutu ir apibrěžiama astronominio dienovidinio kryptis.

Iš (6) formulès išplaukia, kad krypties astronominio azimuto paklaida $\Delta a$, išreiškiama formule

$$
\Delta a=\Delta A_{N}+\Delta Q
$$

priklauso nuo Saulès azimuto paklaidos $\Delta A_{N}$ ir išmatuoto horizontaliojo kampo paklaidos $\Delta Q$. Išsiaiškinsime, kokioms sąlygoms esant Saulès azimutą galima nustatyti tiksliausiai ir kokiu ypatumų turi kampo tarp pasirinktos krypties Žemès paviršiuje ir Saulès matavimas.

\section{Geriausių sąlygų Saulès azimutui nustatyti analizė}

Geodezinèje astronomijoje geriausioms sąlygoms išsiaiškinti taikomos lygtys, siejančios nustatomų dydžių paklaidas su išmatuotų bei žinomų dydžių paklaidomis [1]. Tokią lygti galima parašyti remiantis (1) formule

$$
\begin{aligned}
& \Delta A_{N}=\frac{15 \cos \delta \cos q}{\sin z}(\Delta T+\Delta u-\Delta \alpha)+ \\
& +\frac{\sin A_{N}}{\tan z} \Delta \varphi+\frac{\sin q}{\sin z} \Delta \delta
\end{aligned}
$$

čia $q$ - paralaksinis kampas; $z$ - Saulès zenitinis nuotolis; paklaidos: $\Delta T$ ir $\Delta u$ - chronometro atskaitos ir pataisos, $\Delta \alpha$ ir $\Delta \delta-$ Saulès rektascensijos ir deklinacijos, $\Delta \varphi-$ punkto astronominès platumos. Chronometro pataisos paklaida priklauso nuo punkto astronominès ilgumos paklaidos $\Delta \lambda$. Šią lygti ir taikysime analizuodami geriausias sąlygas.

Iš formulès (8) matyti, kad punkto ir Saulès koordinačiu bei chronometro atskaitos paklaidų itaka mažèja didejjant Saulès zenitiniam nuotoliui.

Saules valandinio kampo paklaidos

$$
\Delta t=\Delta T+\Delta u-\Delta \alpha
$$

itaka priklauso nuo formulès (8) koeficiento $K-$

$$
K=\frac{15 \cos \delta \cos q}{\sin z}
$$

kuris išreiškia Saulès azimuto kitimo greitị. Tikslinga detaliau panagrinèti galimus šio koeficiento pokyčius.

Kaip jau buvo minèta, koeficiento reikšmè mažès didejjant Saulès zenitiniam nuotoliui ir atliekant matavimus Saulei esant arčiau horizonto. $K$ mažès didèjant Saulès deklinacijos absoliučiajai reikšmei.

Koeficientas $K=0$ Saulès vakarinès ir rytinès elongacijos metu $\left(q=90^{\circ}\right.$ arba $\left.270^{\circ}, \cos q=0\right)$. Tačiau Saulès elongacija bus, kai $\delta>\varphi$. Lietuvos teritorijoje ši sąlyga neišpildoma. Saulès elongacija bus tik punktuose, artimesniuose pusiaujui, kurių platumos reikšmè mažesnè už Saulès deklinaciją. Tokiuose punktuose nustatant azimutą pagal Saulès valandini kampą elongacijoms artimais momentais galima labai sumažinti Saulès valandinio kampo paklaidos ittaką.

Remiantis penkiu elementu formule pagal paralaksinį trikampi galima parašyti

$$
\begin{aligned}
& \cos \delta \cos q=\sin \varphi \sin z-\cos \varphi \cos z \cos A_{N}, \\
& \frac{\cos \delta \cos q}{\sin z}=\sin \varphi-\cos \varphi \cot z \cos A_{N}, \\
& K=15\left(\sin \varphi-\cos \varphi \cot z \cos A_{N}\right)
\end{aligned}
$$

Tuomet Saulei esant pirmajame vertikale gauname

$$
K=15 \sin \varphi
$$

Tokia pat koeficiento reikšmė bus ir Saulei patekant bei nusileidžiant horizonte. Saulès azimutą patekèjimo ir nusileidimo momentais galima apskaičiuoti pagal formulę:

$$
\cos A_{N}=\frac{\sin \delta}{\cos \varphi} .
$$

Iš (12) formulès išplaukia, kad Žemès poliuje $K=15^{\prime \prime} / \mathrm{s}$.

Saulès viršutinès kulminacijos metu - tikraji vidurdieni, kai $q=0^{\circ}$ arba $180^{\circ}, \quad$ o $\quad z_{\min }=|\varphi-\delta|$, koeficiento $K$ modulio reikšmė bus maksimali

$$
K_{\max }= \pm \frac{15 \cos \delta}{\sin |\varphi-\delta|}
$$

Koeficientas $K_{\max }$ neigiamas, kai $\delta>\varphi . \quad K_{\max }$ ivvairiais metų momentais ir esant ivvairioms platumos reikšmėms pateikiami 1 lentelèje. 
1 lentelè. $K_{\max }$ reikšmès, "/s

Table 1. $K_{\max }$ values $\quad " / \mathrm{s}$

\begin{tabular}{|c|c|c|c|}
\hline Platuma ${ }^{\circ}$ & $\begin{array}{c}\text { Žiemos } \\
\text { saulègriža } \\
\delta_{\min }=-23^{\circ} 26^{\prime}\end{array}$ & $\begin{array}{c}\text { Lygiadienis } \\
\delta=0^{\circ} 0^{\prime}\end{array}$ & $\begin{array}{c}\text { Vasaros } \\
\text { saulègriža } \\
\delta_{\max }=23^{\circ} 26^{\prime}\end{array}$ \\
\hline 9000 & 15,00 & 15,00 & 15,00 \\
\hline 6500 & 13,77 & 16,55 & 20,74 \\
\hline 5627 & 13,98 & 18,00 & 25,26 \\
\hline 5500 & 14,05 & 18,31 & 26,29 \\
\hline 5354 & 14,11 & 18,56 & 27,15 \\
\hline 4500 & 14,80 & 21,21 & 37,45 \\
\hline 3500 & 16,15 & 26,15 & 68,66 \\
\hline 2000 & 20,02 & 43,86 & $-229,55$ \\
\hline 1000 & 24,98 & 86,38 & $-59,22$ \\
\hline 000 & 34,60 & $\pm \infty$ & $-34,60$ \\
\hline
\end{tabular}

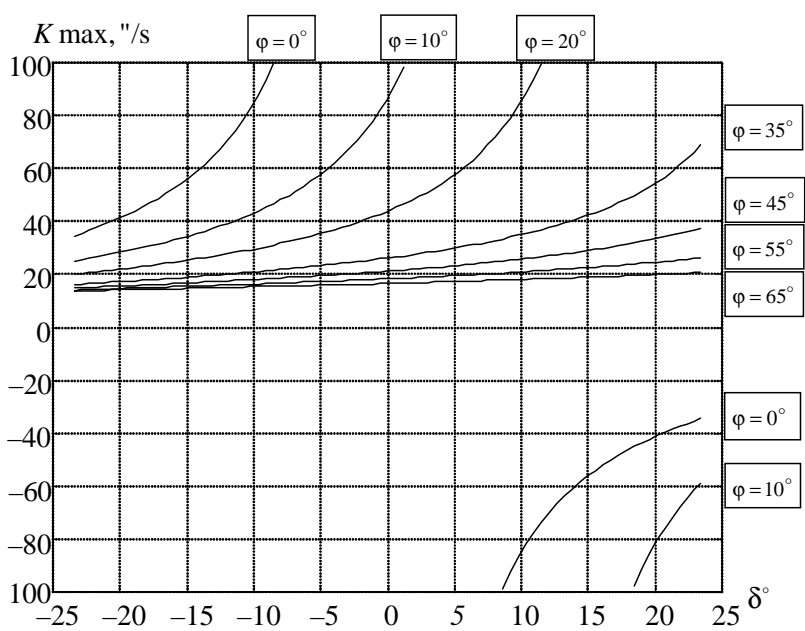

2 pav. $K_{\max }$ priklausomybè nuo Saulès deklinacijos ir punkto platumos

Fig 2. $K_{\max }$ value dependence on the Sun declination and point latitude

$K_{\max }$ priklausomybè nuo Saulès deklinacijos ir punkto platumos reikšmių parodyta 2 pav.

Remdamiesi 1 lenteleje ir 2 pav. pateikta atliktų tyrimų medžiaga išnagrinèsime koeficiento $K_{\max }$ reikšmių kitimą laikotarpiu tarp žiemos ir vasaros saulègrižų, keičiantis Saulès deklinacijai nuo minimalios iki maksimalios reikšmių, o punktų platumai - nuo $90^{\circ}$ iki $0^{\circ}$. Matyti, kad $K_{\max }$ absoliučiosios reikšmès didejja mažèjant platumai. Šiuo laikotarpiu punktų, kurių platuma yra tarp $90^{\circ}$ ir $\varphi=\delta_{\max }, K_{\max }$ reikšmès yra teigiamos ir turi tendenciją didèti. Maksimalios koeficiento reikšmès ir ju pokyčiai, keičiantis Saulès deklinacijai, didèja. Artèjant vasaros saulègrižai ir platumos reikšmèms prie $\varphi=\delta_{\text {max }}$, koeficiento maksimaliosios reikšmès neribotai didèja. Nagrinejjamose platumose yra ir Lietuva $\left(\varphi_{\min }=53^{\circ} 54^{\prime}\right.$, $\left.\varphi_{\max }=56^{\circ} 27^{\prime}\right)$. Jos punktuose $K_{\max }$ reikšmès gali būti nuo $13,98 \mathrm{"} / \mathrm{s}$ iki $14,11 \mathrm{H} / \mathrm{s}$ žiemos saulègrižzos metu ir nuo $25,26 " / \mathrm{s}$ iki $27,15 " / \mathrm{s}$ vasaros saulègrižos metu, priklausomai nuo platumos reikšmès.
Punktuose, kurių platuma tarp $\varphi=\delta_{\max }$ ir $0^{\circ}$, gali būti Saulès elongacijos, kai $\delta>\varphi$. Šiose platumose po žiemos saulègrį̌os $K_{\max }$ reikšmès yra teigiamos ir neribotai didejja artejjant momentui, kai $\delta=\varphi$. Tada $K_{\text {max }}$ igyja neigiamas reikšmes, kurių absoliutusis dydis mažèja iki vasaros saulègrižos.

Laikotarpiu tarp vasaros ir žiemos saulėgrižų $K_{\max }$ keičiasi analogiškai kaip ir pirmaji pusmetị, tik atvirkščia tvarka.

3 pav. parodytas vidutinès Lietuvos platumos koeficiento $K$ kitimas nuo Saulès patekejjimo iki nusileidimo tikrojo Saulès laiko $m_{\circ}$ momentais, esant ivvairioms Saulès deklinacijos reikšmėms.

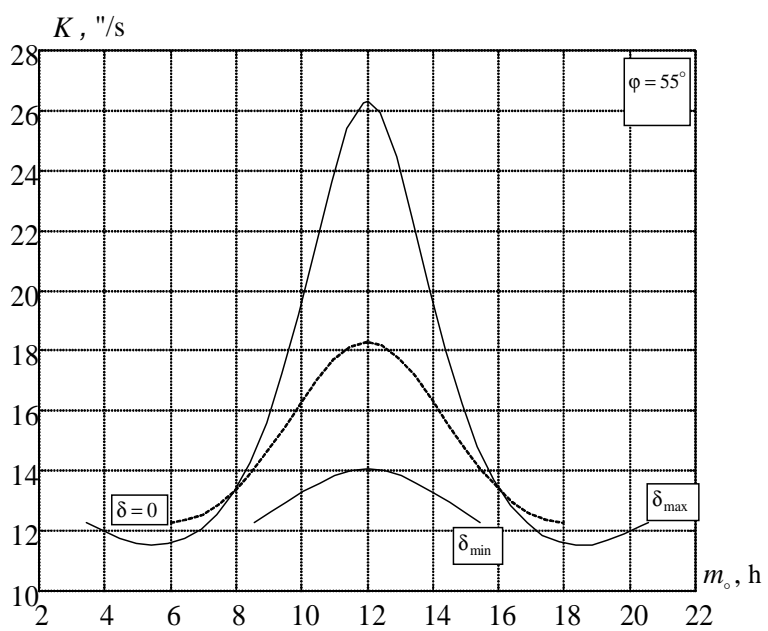

3 pav. Koeficiento $K$ kitimas per dieną

Fig 3. Coefficient $K$ variation during the day

Iš grafiko matyti, kad koeficiento $K$ reikšmiu kreivès simetriškos tikrojo vidurdienio atžvilgiu. Todėl azimutą geriausia nustatyti ryte arba vakare, kai koeficiento reikšmès mažesnès ir Saulès zenitinis nuotolis pakankamai didelis, tačiau neviršija $80^{\circ}$. Didesniais zenitiniais nuotoliais padideja atmosferos svyravimų ir šoninès refrakcijos poveikis. Artejjant žiemos saulègrį̌aai, matavimus galima atlikti nenutraukiant jų net vidurdieni, tačiau bendras matavimams tinkantis laikas per dieną didejja artejant prie vasaros saulègrį̌zos.

Kaip keičiasi koeficiento $K$ reikšmès ivvairiose platumose vasaros ir žiemos saulègrižų dienomis, parodyta 4 ir 5 pav.

Grafikuose matyti, kad koeficiento $K$ reikšmių kreivès simetriškos tikrojo vidurdienio atžvilgiu. Koeficiento reikšmès teigiamos, išskyrus platumas, kuriose yra Saulès elongacijos. Laikotarpiu tarp rytinès ir vakarinès elongacijų koeficiento reikšmès neigiamos. Elongacijų momentais koeficiento reikšmé lygi nuliui. Platumose, kuriose nebūna Saulès elongacijų, koeficiento reikšmès mažiausios rytinėmis ir vakarinėmis valandomis. Koeficiento reikšmių per dieną kitimo intervalas siaurèja, didejjant platumos reikšmėms ir metu laikui artèjant prie žiemos saulègrižos. 


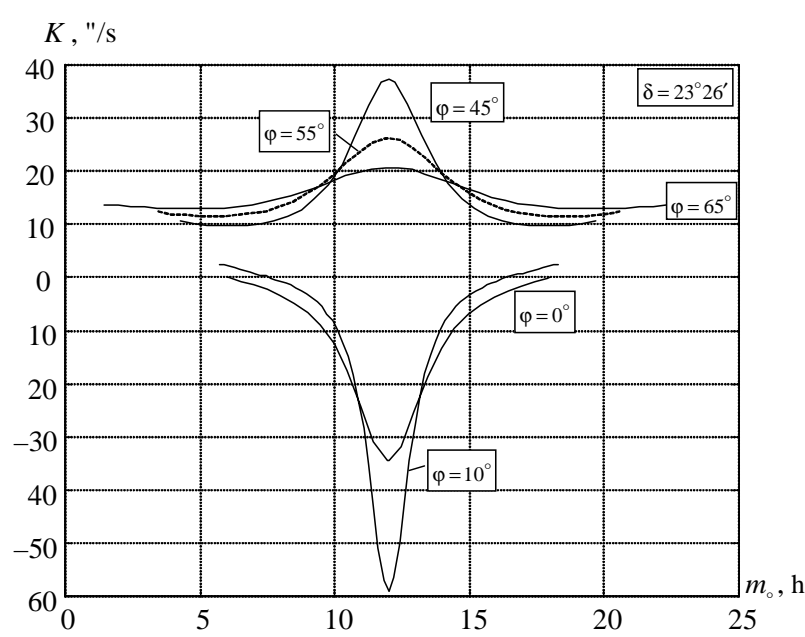

4 pav. Koeficiento $K$ kitimas vasaros saulėgrižos dieną Fig 4. Coefficient $K$ variation during summer solstice day

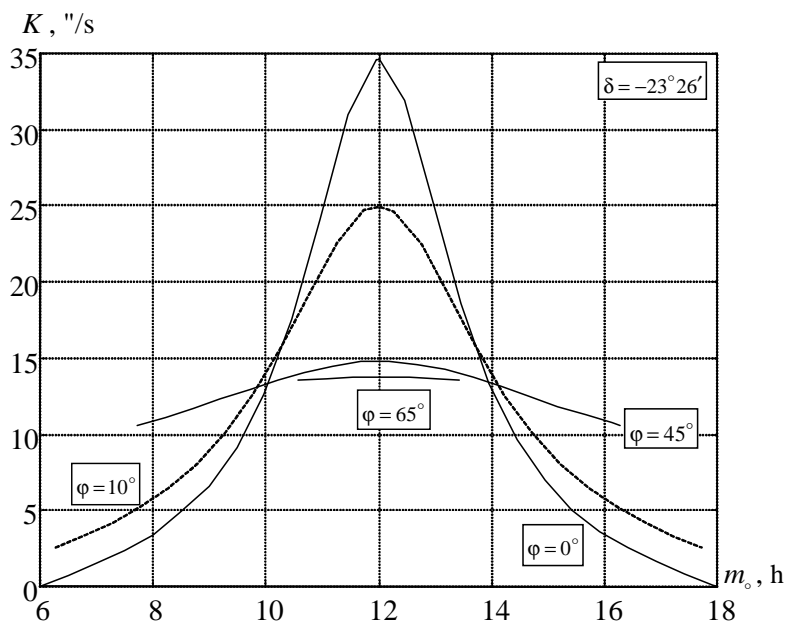

5 pav. Koeficiento $K$ kitimas žiemos saulègrižos dieną Fig 5. Coefficient $K$ variation during winter solstice day

Iš formulès (8) matyti, kad platumos ir Saulès deklinacijos paklaidų ịtaka mažèja artėjant prie dienovidinio ir dienovidinyje lygi nuliui. Šių paklaidu itaką atliekant azimutinius matavimus taip pat galima sumažinti stebint Saulę simetriškai dienovidinio atžvilgiu.

Nustatant krypties astronomini azimutą punkto, kuriame atliekami matavimai, astronominès koordinatès turi būti žinomos. Iš (2) ir (3) formulių matyti, kad ilgumos paklaida turi tiesioginès itakos chronometro pataisos paklaidai $\Delta u$. Todèl atliekant tikslius azimutinius matavimus, ilgumos paklaida turètų būti kiek imanoma mažesnè. Panašios itakos azimuto tikslumui turi ir chronometro atskaitos paklaidos, fiksuojant, kada Saulè kerta vertikaluji teodolito siūlelị. Be to, chronometro rodmenis tenka fiksuoti ir priimant laiko signalus. Todèl atsižvelgiant i koeficiento $K$ reikšmes ir siekiant užsibrěžto azimuto tikslumo galima teigti, kad chronometro rodmenis atliekant azimutinius matavimus reikètų fiksuoti $0,1^{s}$ tikslumu.

Saulès regimąsias pusiaujines koordinates rektascensiją ir deklinacija galima rasti astronominiuose metraščiuose.
Siekiant sumažinti visų paklaidų ittaką pirmiausia reikètų, atsižvelgiant i norimą gauti Saulès azimuto tikslumą ir valandinio kampo paklaida, nusistatyti leistiną koeficiento $K$ reikšmę. Ta reikšmé apibrèžtuc matavimams tinkamiausias Saulès padètis. Platumos ir deklinacijos paklaidų įtaką derètų sumažinti matavimams pasirenkant dienovidiniui simetriškas Saulès padètis.

Nustatydami azimutą platumose, kuriose esti Saulès elongacijos, didžiausią tikslumą pasiektume atlikdami matavimus rytinès ir vakarinès elongacijos metu. Tuomet visų paklaidų poveikis būtų minimalus.

Atliekant mažesnio tikslumo azimutinius matavimus reikètu prisilaikyti bent sąlygos, kad Saulès zenitinis nuotolis būtų nuo $50^{\circ}$ iki $80^{\circ}$.

\section{Horizontaliojo kampo matavimo ypatumų ivertinimas}

Antrają nustatomo krypties astronominio azimuto paklaidos dali sudaro horizontaliojo kampo $Q$ tarp pasirinktos krypties ir Saulès paklaida $\Delta Q$. Jos dydi lemia ne tik prietaiso tikslumas bei matavimu skaičius, bet ir tinkamas matavimo sąlygu įvertinimas.

Saulès regimasis diskas pakankamai didelis, ir negalima tiksliai nutaikyti i jo centrą, todèl matuojant horizontaluji kampa fiksuojamas chronometro rodmuo ir atskaičiuojama horizontaliajame skritulyje, kada Saulès disko kairysis arba dešinysis kraštas kerta teodolito vertikaluji siūleli. Horizontaliojo skritulio atskaita, atitinkanti krypti i Saulès centrą, gaunama pridejus Saulès spindulio pataisa

$$
\Delta_{R}=\frac{R}{\sin z},
$$

čia $R$ - regimasis Saulès spindulys, kuris per metus keičiasi nuo $15^{\prime} 45,4^{\prime \prime}$ liepos pirmosiomis dienomis iki $16^{\prime} 17,5^{\prime \prime}$ sausio pirmosiomis dienomis. Tačiau dažnai skaičiuojamas horizontaliojo skritulio atskaitų, gautų vizuojant i priešingus Saulès kraštus, vidurkis ir Saulès spindulio pataisos nepaisoma. Dèl šios priežasties gali atsirasti išmatuoto kampo reikšmės paklaida, nes tarp matavimų, vizuojant i Saulès priešingus kraštus, praeina tam tikras laiko tarpas, per kuri pasikeičia Saulès zenitinis nuotolis. Saulès zenitinio nuotolio kitimo greitis $v_{z}$ nustatomas pagal žinomas sferinès astronomijos formules:

$$
\begin{aligned}
& v_{z}=15 \cos \varphi \sin A, \\
& v_{z}=15 \cos \delta \sin q .
\end{aligned}
$$

Iš formulių matyti, kad Saulès zenitinio nuotolio maksimalusis greitis bus pirmajame vertikale ir elongacijose:

$$
v_{z \max }=15 \cos \varphi \text { ir } v_{z \max }=15 \cos \delta .
$$


Taigi didžiausias Saulès zenitinio nuotolio kitimo greitis bus pusiaujyje lygiadienio metu - 15"/s. Pirmajame vertikale, $55^{\circ}$ platumoje, jis lygus $8,6 \% / \mathrm{s}$. Kampo $Q$ paklaidas, neįvertinus Saulès spindulio pataisos, galima rasti pagal formulę

$$
\Delta Q_{R}=\frac{R}{2}\left(\frac{1}{\sin z_{1}}-\frac{1}{\sin z_{2}}\right),
$$

čia $z_{1}$ ir $z_{2}-$ Saulès zenitiniai nuotoliai, vizuojant $\mathrm{i}$ priešingus Saulès kraštus. 2 lentelèje pateiktos galimos skirtingų laiko intervalų $\Delta s$ tarp Saulès stebejjimų ir esant skirtingiems zenitiniams nuotoliams paklaidų reikšmès. Atliekant skaičiavimus laikoma, $\operatorname{kad} z_{2}=z_{1}+\Delta z$, $\Delta z=v_{z \max } \Delta s$.

2 lentelè. Paklaidos $\Delta Q_{R}$ reikšmès $\left(\varphi=55^{\circ}, R=977,5^{\prime \prime}\right)$

Table 2. $\Delta Q_{R}$ correction values (when $\varphi=55^{\circ}, R=977,5^{\prime \prime}$ )

\begin{tabular}{|c|c|c|c|c|}
\hline$\Delta s$ & $\begin{array}{c}\Delta z, \\
\quad \prime\end{array}$ & $\begin{array}{c}z_{1}=50^{\circ} \\
\Delta Q_{R} \\
\quad \prime\end{array}$ & $\begin{array}{c}z_{1}=65^{\circ} \\
\Delta Q_{R} \\
\quad \prime\end{array}$ & $\begin{array}{c}z_{1}=80^{\circ} \\
\Delta Q_{R}, \\
\prime \prime\end{array}$ \\
\hline 40 & 344 & 0,9 & 0,4 & 0,1 \\
\hline 80 & 688 & 1,8 & 0,8 & 0,3 \\
\hline 120 & 1032 & 2,7 & 1,2 & 0,4 \\
\hline 160 & 1376 & 3,5 & 1,7 & 0,6 \\
\hline 200 & 1720 & 4,4 & 2,1 & 0,7 \\
\hline 240 & 2064 & 5,3 & 2,5 & 0,8 \\
\hline
\end{tabular}

Matome, kad paklaida $\Delta Q_{R}$ gali būti pastebimos reikšmès, ypač stebint Saulę mažesniais zenitiniais nuotoliais. Paklaida dideja didejant laiko intervalui tarp vizavimų i Saulę. Laiko intervalui sumažinti būtų tikslinga $i$ abu Saulès kraštus vizuoti esant tai pačiai vertikaliojo skritulio padéčiai, tačiau yra metodiku, pagal kurias tai daroma esant skirtingoms vertikaliojo skritulio padėtims. Saulès spindulio pataisą galima apskaičiuoti pagal (19) formulę. Saulès regimasis spindulys astronominiuose metraščiuose pateikiamas kiekvienai dienai.

Kadangi nustatant astronomini azimutą Saulè esti aukštai virš horizonto, tai matuojant kampą $Q$, būtina nustatyti prietaiso horizontaliosios ašies posvyri $b$ ir jo itaką horizontaliajai krypčiai i Saulę. Ašies posvyrio pataisa skaičiuojama pagal formulę

$$
\Delta Q_{b}=b \cot z
$$

Horizontaliosios ašies posvyriui nustatyti, kampo matavimo metu vizuojant ì Saulę, rodmenys atskaitomi ne tik chronometro bei horizontaliojo skritulio, bet ir uždedamo ant horizontaliosios ašies gulsčiuko skalèje. Tyrimais turi būti nustatyta uždedamojo gulsčiuko padalos vertè.

Matuojant kampa $Q$ ir norint sumažinti atsitiktines paklaidas, i Saulę vizuojama keletą kartų. Jeigu prietaisas turi astronomini siūleliu tinklelị, tai fiksuojami chronometro rodmenys, kada Saulè kerta kelis vertikaliuosius siūlelius. Tačiau Saulès azimutas dažnai skaičiuojamas ne kiekvienam Saulès stebėjimo momentui, o vidutiniam momentui:

$$
T_{v}=\frac{1}{n} \sum_{i=1}^{n} T_{i}
$$

čia $T_{i}-$ chronometro atskaitos Saulès stebejjimo momentais; $n$ - Saulès stebèjimų skaičius; $T_{v}$ - vidutinè chronometro atskaita. Tokiu atveju reikia skaičiuoti pagreičio pataisą, nes Saulès azimutas kinta netolygiai. Pagreičio pataisa lanko sekundèmis skaičiuojama pagal formulę [1]

$$
\Delta Q_{a}=\frac{15^{2}}{2 n \rho^{\prime \prime}} \frac{d^{2} A}{d t^{2}} \sum_{i=1}^{n}\left(T_{i}-T_{v}\right)^{2},
$$

čia $\rho^{\prime \prime}$ - sekundžiu skaičius radiane; $\frac{d^{2} A}{d t^{2}}-$ azimuto kitimo pagreitis; $T_{i}-T_{v}-$ chronometro atskaitu skirtumas, išreikštas laiko sekundèmis;

$$
\begin{aligned}
& \frac{d^{2} A}{d t^{2}}=\frac{1}{2}[\sin 2 \varphi \cot z \sin A- \\
& \left.-\cos ^{2} \varphi \sin 2 A\left(\cot ^{2} z+\csc ^{2} z\right)\right] .
\end{aligned}
$$

Iš (22) formulès matyti, kad pagreičio pataisa didès didejjant Saulès azimuto kitimo pagreičiui ir laiko intervalui tarp Saulès stebejjimų. Kaip keičiasi pagreičio pataisa per dieną (vietinio tikrojo Saulès laiko momentais) įvairiais metų laikotarpiais, kai vidutinis chronometro atskaitu skirtumas lygus $100^{s}$, parodyta 6 pav.

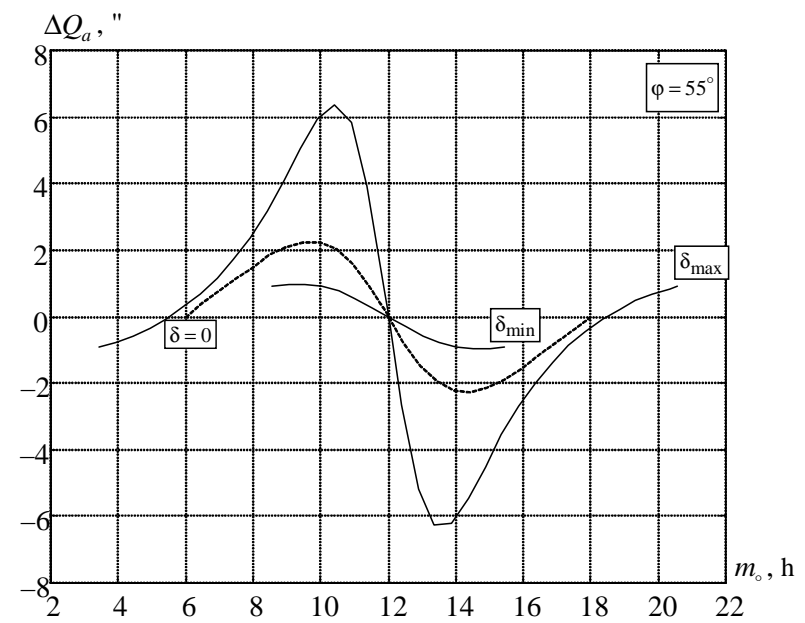

6 pav. Azimuto pagreičio pataisos kitimas Fig 6. Variation of acceleration correction 
Iš grafikų matyti, kad pagreičio pataisos kreivès yra simetriškos tikrojo vidurdienio momento atžvilgiu. Pataisos reikšmių svyravimo diapazonas didžiausias vasaros saulėgrižos metu ir mažèja artejant prie žiemos saulègrižos. Laikotarpiu tarp vasaros saulègrižos ir lygiadienių didesnę laiko prieš tikraji vidurdienį dali pataisa teigiama, po vidurdienio - neigiama. Laikotarpiu tarp žiemos saulègrižos ir lygiadienių prieš vidurdieni pataisa teigiama, po vidurdienio - neigiama.

Nagrinètoms pataisoms skaičiuoti reikalingas Saulès zenitinis nuotolis, todèl tikslinga Saulès stebejimu metu atskaityti ir vertikaluji skrituli.

\section{Metodo taikymas}

Astronominio dienovidinio nustatymo pagal Saulès valandini kampa metodas Lietuvoje taikomas atliekant geomagnetinio lauko amžių variacijų tyrimus [3, 4], kurie svarbūs siekiant kokybiškai spręsti geofizinius, navigacijos, geodinaminius bei kitus uždavinius. Tam tikslui šešiuose Lietuvos teritorijoje įrengtuose punktuose periodiškai matuojami geomagnetinio lauko parametrai. Tokie matavimai atlikti 1999, 2001 ir 2004 metais. Šiuos darbus koordinuoja Nacionalinè žemès tarnyba prie Žemès ūkio ministerijos. Tyrimus atlieka Vilniaus Gedimino technikos universiteto Geodezijos institutas, bendradarbiaudamas su Varšuvos geodezijos ir kartografijos institutu. Atliekamuose geomagnetinio lauko tyrimuose matavimu rezultatams redukuoti naudojami Belsko (Lenkija) geomagnetinès observatorijos duomenys [5].

Atliekant geomagnetinio lauko tyrimus labai svarbu kampo tarp astronominio ir magnetinio dienovidiniu, t. $\mathrm{y}$. magnetinès deklinacijos, nustatymas. Ši dvisieni kampa apibrěžia punkto, kuriame atliekami matavimai, vertikalè ir abieju - astronominio bei magnetinio dienovidiniu plokštumos. Astronominio dienovidinio plokštuma lygiagreti su pasirinktos epochos Žemès sukimosi ašimi, o magnetinio dienovidinio plokštuma - tos pačios epochos Žemès magnetinio lauko ašimi. Tikslios magnetinès deklinacijos reikšmès taip pat gaunamos geomagnetinèse observatorijose, tarptautiniuose oro uostuose [6]. Magnetinio dienovidinio plokštuma randama naudojant magnetometrus [3], o astronominio dienovidinio krypti galima apskaičiuoti pagal Saulès valandinį kampa [1].

\section{Išvados}

1. Nustatant astronominio dienovidinio krypti pagal Saulès valandini kampą ir siekiant sumažinti visu paklaidu itaką, pirmiausia reikia, atsižvelgiant i norimą gauti Saulès azimuto tikslumą ir valandinio kampo paklaidą, nusistatyti leistinas koeficiento $K$ reikšmes. Šios reikšmès apibrèžia tinkamiausias matavimams Saulès padètis. Matavimu metu Saulès zenitinis nuotolis neturi viršyti $80^{\circ}$. Platumos ir Saulès deklinacijos paklaidu itaką galima sumažinti pasirenkant matavimams dienovidiniui simetriškas Saulès padètis.

2. Nustatant astronomini dienovidini ir azimuta platumose, kuriose esti Saulès elongacijos, didžiausią tikslumą galima pasiekti atliekant matavimus rytinès ir vakarinès elongacijos metu. Tuomet visu paklaidu itaka minimali.

3. Pageidautina, kad prietaisas, naudojamas astronominiam dienovidiniui nustatyti, turètu gulsčiuka, uždedamą ant horizontaliosios ašies, ir astronomini siūlelių tinklelị. Matuojant horizontaluji kampa tarp pasirinktos krypties ir Saulès, uždedamuoju gulsčiuku reikia ỉvertinti prietaiso horizontaliosios ašies posvyrị. Saulès perèjimų momentus reikia fiksuoti $0,1^{s}$ tikslumu.

4. Skaičiuojant Saulès azimutą vidutiniam momentui reikia ivertinti Saulès spindulio ir jos azimuto kitimo pagreičio pataisas.

\section{Literatūra}

1. Uralov, S. S. Geodetic astronomy (Курс геодезической астрономии). Moscow: Nedra, 1980. 592 p. (in Russian).

2. Abalakin, V. K.; Krasnorilov, I. I.; Plahov, J. V. Geodetic astronomy and astrometry (Геодезическая астрономия и астрометрия). Moscow: Kartgeocentr-Geodezizdat, 1996. 434 p. (in Russian).

3. Sas-Uhrynowski, A.; Mroczek, S.; Abromavičius, R.; Obuchowski, R. Investigations of the magnetic field over the territory of Lithuania. Geodesy and Cartography (Geodezija ir kartografija), Vol XXVIII, No 3, Vilnius: Technika, 2002, p. 88-94.

4. Jucevičiūtè, V.; Kumetaitis, Z.; Šleiteris, E.; Būga, A.; Obuchowski, R.; Paršeliūnas, E. K.; Petroškevičius, P.; Putrimas, R. Trends of development of the Lithuanian national geodetic control. In: Mitteilungen des Bundesamtes für Kartographie und Geodäsie: Report on the Symposium of the IAG Subcommission for Europe (EUREF) held in Ponta Delgada, Euref Publication, No 12, Band 29, ISSN 1436-3445, 2003, p. 273-281.

5. Kowalik B.; Obuchovski R. Investigation of geomagnetic field on the Lithuanian territory. In: The 6-th International Conf „Environmental Engineering“ selected papers, Vol 2, Vilnius: Technika, 2005, p. 908-912.

6. Newitt, L. R.; Barton, C. E.; Bitterly, J. Guide for magnetic repeat station surveys. IAGA, published by SecretaryGeneral of IAGA, WGV-8, NOAA space Environment Center, Boulder, CO 80303-3328, USA, printed in Warsaw, 1996. $112 \mathrm{p}$.

Petras Petroškevičius. Professor, Doctor Habil. Vilnius Gediminas Technical University. Dept of Geodesy and Cadastre (Ph, Fax +37052744705), e-mail: gi@ ap.vtu.lt.

Author of 1 monograph and more than 100 scientific publications. Participated in many intern conferences.

Research interests: determination of Earth satellites orbits, research of Earth gravity field by means of satellite geodesy and gravimetric methods, establishment of geodetic and gravimetric networks.

Romuald Obuchovski. Doctoral student. Vilnius Gediminas Technical University. Dept of Geodesy and Cadastre (Ph, Fax +37052744705), e-mail: gi@ ap.vtu.lt.

Author of 10 scientific papers.

Research interests: Earth magnetic field investigations. 